\title{
PENGARUH EKSTRAK Tamarindus indica TERHADAP KENAIKAN BERAT BADAN PADA TIKUS Rattus novergicus YANG DIBERI DIET OBESITAS
}

\author{
Candra Rini Hasanah Putri ${ }^{{ }^{*}}$, Titiek Sunaryati ${ }^{2}$ \\ Bagian Anatomi Fakultas Kedokteran Universitas Wijaya Kusuma Surabaya ${ }^{1}$ \\ Bagian Patologi Anatomi Fakultas Kedokteran Universitas Wijaya Kusuma Surabaya ${ }^{2}$ \\ Jl. Dukuh Kupang XXV/ 54, Surabaya \\ e-mail: candrarinihp75@gmail.com
}

\begin{abstract}
Abstrak
Obesitas merupakan masalah kesehatan yang prevalensinya cenderung meningkat di Indonesia. Obesitas menjadi hal yang perlu diperhatikan, karena merupakan salah satu parameter yang sering menyertai gangguan toleransi glukosa dalam sindroma metabolik. Di Indonesia, Tamarindus indica dipercaya merupakan bahan pelangsing tubuh sehingga mempunyai kemungkinan untuk menjadi terapi alternatif yang mudah didapat dan murah bagi obesitas. Tujuan penelitian ini adalah mengetahui kemampuan Tamarindus indica dalam menghambat obesitas. Penelitian pada hewan coba menggunakan 28 ekor tikus putih jantan strain Wistar dengan umur 2-3 bulan yang dibagi dalam 4 kelompok yaitu kelompok 1 (kontrol negatif, diet normal tanpa Tamarindus indica), kelompok 2 (kontrol positif, diet obesitas tanpa Tamarindus indica), kelompok 3 (diet obesitas + dosis Tamarindus indica $2700 \mathrm{mg} / \mathrm{kgBB}$ ), dan kelompok 4 (diet obesitas + dosis Tamarindus indica $3600 \mathrm{mg} / \mathrm{kgBB}$ ). Dilakukan pengukuran berat badan pada hari pertama setelah aklimatisasi sebelum diberi perlakuan (hari ke 8), dan diulang tiap minggu setelahnya yaitu pada hari ke 15, 22, 29, 36, dan 43. Analisis statistik dengan uji Anova dan Tukey Simultaneous Test untuk melihat perbedaan kenaikan berat badan tiap minggu dibandingkan dengan minggu pertama penelitian, yang kemudian diperbandingkan antar kelompok. Selanjutnya dilakukan skrining virtual dengan analisis bioinformatika insilico yang menguji ikatan antara quercetin dan rutin (senyawa dalam Tamarindus indica) dengan fatty acid synthase, enzim yang berperan dan sintesis de novo asam lemak. Tamarindus indica terbukti secara signifikan menghambat kenaikan berat badan pada tikus yang diberikan diet obesitas $(P=0,000)$, tetapi perbedaan dosis Tamarindus indica tampaknya tidak berpengaruh secara signifikan ( $P=0,321)$. Kemampuan Tamarindus indica tersebut disebabkan karena kandungan quercetin dan rutin di dalamnya, dimana dua bahan ini diperkirakan mempunyai kemampuan inhibisi terhadap fatty acid synthase dengan kekuatan yang tinggi.
\end{abstract}

Kata Kunci: berat badan, fatty acid synthase, Tamarindus indica

\section{THE EFFECT OF Tamarindus indica EXTRACT ON WEIGHT GAIN ON Rattus novergicus RATS WITH OBESE DIET FOOD}

\begin{abstract}
Obesity is a health problem whose prevalence tends to increase in Indonesia. Obesity becomes a concern, because it is one of the parameters that often followed by impaired of glucose tolerance in the metabolic syndrome. In Indonesia, Tamarindus indica is believed as a body slimming substance so it has possibility to become an alternative therapy that is easily available and cheap for obesity. The purpose of this study was to determine the ability of Tamarindus indica in inhibiting obesity. This experiment used 28 male Wistar strains in 2-3 months age that were divided into groups: group 1 (negative control, normal diet without Tamarindus indica), group 2 (positive control, obese diet without Tamarindus indica), group 3 (obese diet +Tamarindus indica $2700 \mathrm{mg} / \mathrm{kg} \mathrm{BW}$ ), and group 4 (obese diet + Tamarindus indica $3600 \mathrm{mg} / \mathrm{kg} \mathrm{BW})$. Measurement were performed in the first day after acclimization before treatment (day 8), and repeated weekly afterwards, ie at day 15, 22, 29, 36, and 43. Anova and Tukey Simultaneous statistics test were performed to see the differences in wight gain per week compared with
\end{abstract}


the first week of study, then compared between groups. Furthermore, a virtual screening that called insilico bioinformatics analyzes was performed to test the binding activity between quercetin and rutin (compounds in Tamarindus indica) with fatty acid synthase, an enzym that plays a role in de novo synthesis of fatty acids. Tamarindus indica was shown to significantly inhibit weight gain in rats with obese diet food $(P=0.000)$, but differences dose of Tamarindus indica did not appear to have significant effect to inhibit obesity $(P=0.321)$. The ability of Tamarindus indica is due to the compounds quercetin and rutin, where these two ingredients estimated to have the ability to inhibit fatty acid synthase with high strength.

Keywords: fatty acid synthase, Tamarindus indica, weight gain

\section{PENDAHULUAN}

Berbagai penelitian telah menyatakan bahwa terjadi peningkatan prevalensi obesitas di dunia (1). Dilndonesia juga terdapat peningkatan prevalensi obesitas, dimana prevalensi penduduk laki-laki dewasa obesitas pada tahun 2013 sebanyak 19,7 persen, lebih tinggi dari tahun 2007 (13,9\%) dan tahun 2010 $(7,8 \%)(2)$. Obesitas juga dapat menimbulkan komplikasi berupa sindroma metabolik yang merupakan suatu kelainan kompleks dan menjadi penyakit epidemik di seluruh dunia. Bahkan menurut WHO, obesitas (yang diukur dengan rasio pinggang/pinggul atau dengan indeks massa tubuh (BMI) menjadi salah satu parameter penyerta di dalam penegakan diagnosa sindroma metabolik bersama dengan adanya resistensi insulin atau adanya gangguan toleransi glukosa atau diabetes mellitus tipe 2 sebagai komponen utama sindroma metabolik ini (3).

Sementara itu, kini semakin marak penggunaan bahan-bahan alamiah untuk tujuan kesehatan. Salah satu bahan alami yang dipercaya berperan pada kesehatan adalah Tamarindus indica. Di Indonesia, bahan ini disebut sebagai asam jawa (4).Di Indonesia, Tamarindus indica dipercaya mempunyai berbagai khasiat dalam kesehatan, diantaranya sebagai bahan pelangsing tubuh (5).

Penggunaan Tamarindus indica sebagai obat tradisional untuk pelangsing dan diabetes tersebut menjadi menarik untuk diteliti, mengingat tanaman asam jawa ini merupakan tanaman yang banyak terdapat di Indonesia pada umumnya, dan di kota Surabaya pada khususnya. Kemudahan dalam mendapatkan bahan alamiah ini menyebabkan Tamarindus indica dapat mempunyai kemungkinan untuk menjadi terapi alternatif yang mudah didapat dan murah bagi keadaan obesitas. Hal tersebut mendasari penelitian ini, dimana pada penelitian ini bertujuan untuk mengetahui pengaruh pemberian diet ekstrak Tamarindus indica terhadap kenaikan berat badan pada tikus yang diberikan diet obesitas.

\section{METODE PENELITIAN}

Penelitian ini terbagi menjadi 2 tahap, dimana tahap 1 merupakan penelitian eksperimental murni, dengan rancangan randomizedcontrol group pretest post test design dengan lokasi penelitian di Laboratorium Hewan Coba Fakultas Kedokteran Universitas Wijaya Kusuma Surabaya, yang dilanjutkan dengan tahap 2 yaitu skrining virtual dengan analisis bioinformatika in-silico untuk menguji ikatan antara quercetin dan rutin (senyawa dalam Tamarindus indica) dengan fatty acid synthase, enzim yang berperan dan sintesis de novo asam lemak.

Persiapan ekstrak Tamarindus indica. 300gram Tamarindus indica dengan 750 $\mathrm{ml}$ aquades, kemudian dimasak hingga mendidih, dievaporasi selama 4 jam dalam suhu $40^{\circ} \mathrm{C}$, lalu dioven selama 4 jam dalam suhu $38^{\circ} \mathrm{C}$, diblender, lalu ditimbang sesuai dosis masing-masing tikus, dan dimasukkan dalam toples kecil. Bahan diencerkan dengan ditambah $0,5 \mathrm{ml}$ aquades, dan kemudian disimpan dalam lemari es dengan suhu $4^{\circ} \mathrm{C}$ hingga digunakan.

\section{Pembagian Kelompok Hewan Coba.}

28 ekor tikus putih jantan strain Wistar yang berjumlah 28 ekor dengan umur 2-3 bulan dibagi dalam 4 kelompok secara acak yaitu kelompok kontrol negatif (diet normal tanpa Tamarindus indica), kelompok kontrol positif (diet obesitas tanpa Tamarindus indica), kelompok Tamarindus indica dosis kecil (diet 
obesitas + dosis Tamarindus indica $2700 \mathrm{mg} / \mathrm{kgBB}$ ), dan kelompok Tamarindus indica dosis besar (diet obesitas + dosis Tamarindus indica $3600 \mathrm{mg} / \mathrm{kgBB}$ ). Sebelum diberi perlakuan, tikus diberi masa aklimatisasi selama 7 hari. Dilakukan pengukuran berat badan dankadar gula darah, setelah proses aklimatisasi selesai dan sebelum mulai diberi perlakuan (hari ke 8), dan diulang tiap minggu setelahnya yaitu pada hari ke 15, 22, 29, 36, 43.

Diet Tikus pada Penelitian.

Tikus kelompok kontrol negatif diberi makan berupa diet tikus normal (standar), dan minum air PDAM ad libitum. Sedangkan tikus kelompok lain mendapat makanan diet obesitas dan minum air PDAM ad libitum. Diet obesitas dibuat dengan komposisi khusus yang mengandung lemak tinggi, dimana dari 100\% pakan tikus dalam sehari diberikan pakan biasa bentuk pellet BR1 $10 \%$, dan ditambahkan sonde yang berisi jelantah $45 \%$, kuning telur bebek dicampur gula halus $45 \%$.

Pengambilan Data Berat Badan Tikus. Penimbangan berat badan tikus dengan timbangan merk Camry dalam satuan gram. Tikus ditimbang dalam toples plastik, dimana sebelum penimbangan, alat sudah diatur sehingga berat toples tidak terhitung. Dilakukan pengukuran berat badan pertama setelah proses aklimatisasi selesai dan sebelum mulai diberi perlakuan (hari ke 8), dan diulang tiap minggu setelahnya yaitu pada hari ke 15 , 22, 29, 36, dan 43.

Analisis Bioinformatika In-silico.

Dua bahan aktif dalam Tamarindus indica, quercetin dan rutin (6) diinteraksikan dengan protein yang berperan dalam pembentukan asam lemak, yaitu fatty acid synthase (FAS) dengan cara molecular docking.Struktur protein FAS didapatkan dari database struktur protein hasil experiment di PDB BANK (www.rcsb.org) (4W9N) yang dimodelling dengan menggunakan SWISS Model, kemudian dipreparasi dengan program PyMOL.

Senyawa quercetin (5280343) dan rutin (5280805) didapatkan dari database PUB CHEM (https:// pubchem.ncbi.nlm.nih.gov),

diminimisasi untuk mendapatkan konformasi yang paling cocok dengan OpenBabel di PyRx.
Proses molecular docking dilakukan secara spesifik pada sisi aktif FAS (sesuai referensi), dengan menganalisis sisi pengikatan inhibitor (triclosan) pada FAS (7). Inhibitor alami FAS (triclosan) dipisahkan kemudian dijadikan kontrol dalam proses docking. Apabila quercetin ataupun rutin memiliki sisi pengikatan dan afinitas yang tinggi seperti halnya triclosan maka quercetin maupun rutin sebagai bahan aktif dalam Tamarindus indica dapat dipertimbangkan sebagai inhibitor FAS yang berpotensi. Proses docking dilakukan menggunakan Autodock Vina di PyRx 0.8.

\section{HASIL}

\section{Pengaruh Pemberian Diet Ekstrak Tamarindus indica terhadap Berat Badan Tikus Rattus novergicus}

Pada penelitian ini didapatkan perbedaan kenaikan berat badan yang signifikan antar kelompok $(\mathrm{P}=0,000)$. Tampak dari Gambar 1 dengan nilai signifikansi dapat dilihat pada Tabel 1, antara kelompok 1 (kelompok diet normal) dengan kelompok 2 (kelompok diet obesitas) tidak terdapat perbedaan yang signifikan yang menunjukkan bahwa pemberian diet obesitas tidak dapat menyebabkan kenaikan berat badan secara signifikan $(P=0,759)$. Tetapi terdapat perbedaan yang signifikan antara kelompok 2 (kelompok diet obesitas) dan 3 (kelompok diet obesitas + TI $2700 \mathrm{mg} / \mathrm{kgBB}$ ) yaitu dengan $\mathrm{P}=0.0000$, serta antara kelompok 2 (kelompok diet obesitas) dan 4 (kelompok diet obesitas + TI $3600 \mathrm{mg} / \mathrm{kgBB}$ ) dengan $\mathrm{P}=0,000$, yang menunjukkan bahwa pemberian Tamarindus indica dapat menurunkan kenaikan berat badan secara signifikan. Antara kelompok 1 (kelompok diet normal) dengan kelompok 3 (kelompok diet obesitas + Tl $2700 \mathrm{mg} / \mathrm{kgBB}$ ) maupun dengan kelompok 4 (kelompok diet obesitas + $\mathrm{TI} 3600 \mathrm{mg} / \mathrm{kgBB}$ ), juga terdapat perbedaan yang signifikan dengan masing-masing $P=0,000$. Kelompok 3 (kelompok diet obesitas $+\mathrm{TI}$ $2700 \mathrm{mg} / \mathrm{kgBB}$ ) dan 4 (kelompok diet obesitas + TI $3600 \mathrm{mg} / \mathrm{kgBB}$ ) tidak berbeda secara signifikan, dimana $\mathrm{P}=0,321$. 
ISSN 1978-2071 (Print); ISSN 2580-5967 (Online)

Jurnal IImiah Kedokteran Wijaya Kusuma 6 (1) : 1-7

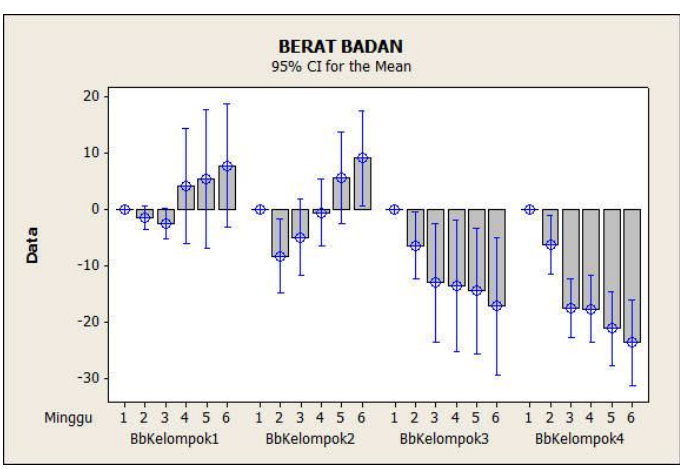

Gambar 1. Diagram Batang Berat Badan

Tabel 1. Perbedaan Kenaikan Berat Badan Antar Kelompok

Kenaikan Berat Badan, Anova Tukey Simultaneous Test

\begin{tabular}{|l|l|l|l|l|}
\hline & Kelompok 1 & Kelompok 2 & Kelompok 3 & Kelompok 4 \\
\hline Kelompok 1 & & $\mathrm{P}=0.7596$ & $\mathrm{P}=0.0000$ & $\mathrm{P}=0.0000$ \\
\hline Kelompok 2 & & & $\mathrm{P}=0.0000$ & $\mathrm{P}=0.0000$ \\
\hline Kelompok 3 & & & & $\mathrm{P}=0.3211$ \\
\hline
\end{tabular}

*Signifikan bila $\mathrm{P} \varangle 0.005$

\section{Hasil Analisis Bioinformatika In-Silico}

Hasil insilico menunjukkan bahwa quercetin mampu berikatan dengan FAS di tempat yang sama seperti halnya tempat ikatan triclosan dengan FAS (tampak pada Gambar 2) dimana kekuatan ikatannya (binding affinity 7.6) lebih besar dari pada kekuatan ikatan antara triclosan dengan FAS (binding affinity 7.2), sesuai dengan Tabel 2. Rutin juga dapat berikatan dengan FAS di tempat yang sama seperti halnya tempat ikatan triclosan dengan FAS (Gambar 3), dengan kekuatan ikatannya (binding affinity -8.7) yang bahkan lebih besar lagi dari pada kekuatan ikatan antara triclosan dengan FAS (binding affinity -7.2) maupun antara quercetin dan FAS, sesuai dengan Tabel 2.

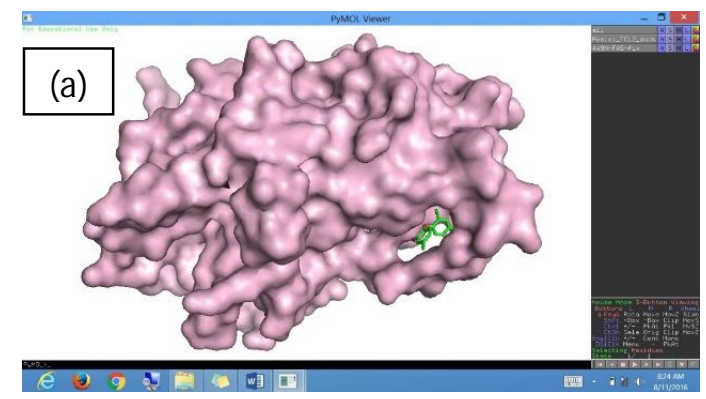

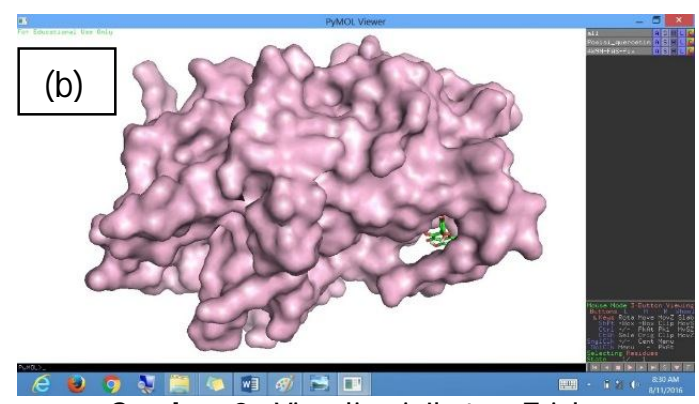

Gambar 2. Visualisasi Ikatan TriclosanFAS dan quercetin-FAS dengan menggunakan PyM olPyM ol. (a) Antara triclosan dengan Fatty Acid Synthase. (b) Antara quercetin dengan Fatty Acid Synthase
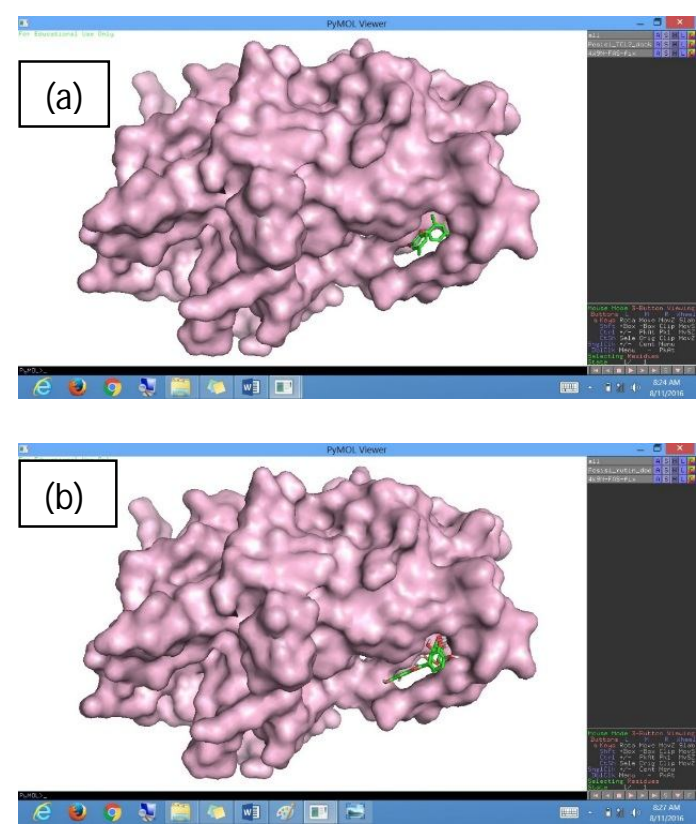

Gambar 3. Visualisasi Ikatan TriclosanFAS dan Rutin-FAS dengan menggunakan PyM ol. (a) Antara triclosan dengan Fatty Acid Synthase. (b) Antara rutin dengan Fatty Acid Synthase

Tabel 2. Perbandingan Kekuatan Binding Affinity Quercetin, rutin, dan Triclosan Terhadap FAS

\begin{tabular}{lc}
\hline & Binding Affinity terhadap FAS \\
\hline Triclosan & $-7,2$ \\
\hline Quercetin & $-7,6$ \\
\hline Rutin & $-8,7$ \\
\hline
\end{tabular}

*Semakin negatif (-) menunjukkan kekuatan ikatan yang semakin besar 


\section{DISKUSI}

Pemberian diet ekstrak Tamarindus indicapada tikus Rattus novergicus pada penelitian ini ternyata menunjukkan adanya pengaruh yang signifikan terhadap kenaikan berat badan tikus (dengan $\mathrm{P} \varangle 0.05$ ), dimana dari dari hasil penelitian terdapat perbedaan yang signifikan antara kelompok 2 (kelompok diet obesitas) dan 3 (kelompok diet obesitas $+\mathrm{TI}$ $2700 \mathrm{mg} / \mathrm{kgBB}$ ) yaitu dengan $\mathrm{P}=0.0000$, serta antara kelompok 2 (kelompok diet obesitas) dan 4 (kelompok diet obesitas $+\mathrm{TI}$ $3600 \mathrm{mg} / \mathrm{kgBB}$ ) dengan $\mathrm{P}=0.0000$, yang menunjukkan bahwa pemberian Tamarindus indica dapat menurunkan kenaikan berat badan secara signifikan pada tikus dengan diet obesitas. Antara kelompok 1 (kelompok diet normal) dengan kelompok 3 (kelompok diet obesitas + TI $2700 \mathrm{mg} / \mathrm{kgBB}$ ) maupun dengan kelompok 4 (kelompok diet obesitas + TI $3600 \mathrm{mg} / \mathrm{kgBB})$, juga terdapat perbedaan yang signifikan dengan masing-masing $P=0.0000$, yang menunjukkan bahwa pada kelompok dengan diet obesitas, pemberian Tamarindus indica dapat menurunkan kenaikan berat badan tikus bahkan melebihi kelompok dengan diet normal. Kelompok 3 (kelompok diet obesitas + TI 2700mg/kgBB) dan 4 (kelompok diet obesitas + TI 3600mg/kgBB) menunjukkan hasil yang tidak berbeda secara signifikan, dimana $\mathrm{P}=0.3211$, menunjukkan bahwa perubahan dosis kurang berperan.

Hasil penelitian ini sesuai dengan beberapa penelitian terdahulu yang telah dilakukan. Penelitian 28 hari yang telah dilakukan oleh Ukwuani dkk (8) terhadap tikus menunjukkan bahwa pemberian ekstrak buah Tamarindus indica disertai diet biasa dapat menurunkan berat badan secara signifikan. Hasil yang sama didapatkan dari beberapa penelitian lain, walaupun dengan menggunakan metode yang sedikit berbeda $(9,10)$. Walaupun demikian penelitian lain terhadap manusia menunjukkan hasil yang berbeda (11), dimana pada manusia pemberian Tamarindus indica tidak menunjukkan efek yang nyata pada berat badan, walaupun dapat menurunkan kolesterol secara signifikan. Dengan demikian, penelitian kali ini menambahkan bukti mengenai adanya pengaruh dari diet buah Tamarindus indica terhadap hambatan peningkatan berat badan pada subyek yang diberikan diet obesitas.
Pengaruh buah Tamarindus indica terhadap berat badan dapat dijelaskan dari sisi pengaruhnya terhadap fatty acid synthase (FAS). Penelitian oleh Azman dkk (9) menyatakan bahwa Tamarindus indica dapat menurunkan FAS. FAS merupakan enzim yang mengkondensasi 1 molekul acetyl-CoA dan 7 malonyl-CoA menjadi palmitat, yang selanjutnya dimodifikasi menjadi berbagai lipid. FAS berperan pada sintesis asam lemak secara de novo $(12,13)$.Padasintesis asam lemak de novo, glukosa yang berlebih dari intake akan mengalami glikolisis dan selanjutnya melalui siklus Kreb dalam mitokondria, dan kemudian keluar dari mitokondria sebagai sitrat, yang selanjutnya diubah menjadi acetyl-CoA oleh ATP citrate lyase. Acetyl-CoA dapat mengalami karboksilasi menjadi malonyl-CoA dengan dikatalisa oleh acetyl-CoA carboxylase (ACC). FAS berfungsi dalam melakukan kondensasi satu acetyl-CoA dan tujuh malonyl-CoA menjadi palmitat yang kemudian dimodifikasi menjadi berbagai lipid (13), yang kemudian akan ikut membentuk sel lemak dalam jaringan adiposa. Dengan demikian, peran Tamarindus indica yang dapat menurunkan FAS tersebut mungkin yang menjadi mekanisme sehingga Tamarindus indica dapat menghambat pembentukan jaringan adiposa sehingga selanjutnya menghambat peningkatan berat badan.

Buah Tamarindus indica sendiri diketahui mengandung beberapa antioksidan, diantaranya adalah quercetin dan rutin (6). Berdasarkan kajian bioinformatika (in-silico) yang kami lakukan, didapatkan hasil bahwa baik quercetin maupun rutin dapat mengikat FAS pada tempat yang sama dengan inhibitor FAS yang telah diketahui sebelumnya (pada studi tersebut kami membandingkan dengan triclosan yang telah dikenal sebagai FAS inhibitor)(7). Studi yang lebih lanjut menunjukkan bahwa ternyata ikatan quercetin maupun rutin terhadap FAS lebih kuat dibandingkan ikatan triclosan terhadap FAS. Hal ini menunjukkan adanya potensi inhibisi dari quercetin dan rutin (sebagai bahan aktif dalam Tamarindus indica) terhadap FAS yang lebih besar daripada potensi inhibisi triclosan. Kemampuan dari bahan-bahan aktif dalam Tamarindus indica (quercetin dan rutin) untuk berikatan dengan FAS dan berada di tempat yang sama dengan tempat ikatan dari triclosan tersebut mungkin merupakan mekanisme kunci kerja Tamarindus indica dalam 
menghambat peningkatan berat badan pada tikus yang telah diberi diet obesitas.

\section{KESIM PULAN}

Kesimpulan yang dapat diambil dari penelitian ini adalah:

1. Pemberian diet Tamarindus indica (kelompok 3 dan 4) berpengaruh signifikan terhadap penurunan kenaikan berat badan tikus yang mendapat diet obesitas (masing-masing dengan $P=0.0000$ dan $\mathrm{P}=0.0000$ dibandingkan dengan kelompok 2).

2. Penurunan kenaikan berat badan tersebut bahkan hingga melebihi kelompok diet normal (masing-masing $\mathrm{P}=0.0000$ dibandingkan dengan kelompok 1 )

3. Perbedaan dosis Tamarindus indica (antara kelompok 3 dan 4) tidak berpengaruh secara signifikan pada berat badan $(P=0.3211)$.

4. Senyawa aktif yang berperan dalam kemampuan Tamarindus indica untuk menghambat kenaikan berat badan adalah quercetin dan rutin, yang mampu berikatan dengan FAS dengan binding affinity lebih kuat daripada triclosan sebagai inhibitor referensi (quercetin -7.6, rutin -8.7 , triclosan -7.2 ).

\section{SARAN}

Perlu dilakukan penelitian dengan perbedaan dosis Tamarindus indica yang lebih besar, dikarenakan pada penelitian ini tampaknya perbedaan dosis masih kurang sehingga perbedaan masih belum signifikan.

\section{DAFTAR PUSTAKA}

1. Rasouli N and Kern PA. 2008. Adipocytokines and the Metabolic Complication of Obesity. J Clin Endocrinol M etab 93(11 Suppl 1): S64-S73

2. Riset Kesehatan Dasar (Riskesdas). 2013. Badan Penelitian dan Pengembangan Kesehatan Kementrian Kesehatan RI. Available from http://www.depkes.go.id/resources/down load/general/Hasil\%20Riskesdas\%202013. pdf
3. Kassi E, Pervanidou P, Kaltsas G, Chrousos G. 2011. Metabolic Syndrome: Definitions and Controversies. BM C M edicine 9:48

4. Ranjan D, Swarup D, Patra RC, Chandra V. 2009. Tamarindus indica $L$. and M oringa oleifera M. Extract Administration Ameliorates Fluoride Toxicity in Rabbits. Indian Journal of Experimental Biology Vol 47 pp 900-90

5. Soemardji AA. 2007. Tamarindus indica L. or "Asam Jawa": The Sourbut Sweet and Useful. Available from www.inm.utoyama.ac.jp/jp/nennpo/07nennpo/07rev iew article.pdf

6. Amir M, Mujeeb M, Ahmad S, Akhtar M, Ashraf K. 2013. Design expert-supported development and validation of HPLC method: An application in the simultaneous estimation of quercetin and rutin in Punica granatum, Tamarindus indica and Prunus domestica. Pharmaceutical M ethods 4 (2013) 62-67

7. Sippel KH, Vyas NK, Sankaran B, Quiocho FA. 2014. Crystal Structure of the Human Fatty Acid Synthase Enoyl-Acyl Carrier Protein-Reductase Doman Complexed with Triclosan Reveals Allosteric ProteinProtein Interface Inhibition. THE JOURNAL OF BIOLOGICAL CHEMISTRY, Vol 289, No 48, pp 33287-33295

8. Ukwuani AN, Abukakar MG, Shehu RA, Hassan LG. 2008. Antiobesity Effect of Pulp Extract Tamarindus indica in Albino Rat. Asian Journal of Biochemistry 3(4) pp 221-228

9. Azman KF, Amom Z, Azlan A, Esa NM, Ali RM, Shah ZM, Kadir KKA. 2011.

Antiobesity Effect of Tamarindus indica L. Pulp Aqueous Extract in High-Fat DietInduced Obese Rats. J Nat M ed

10. Jindal V, Dhingra $D$, Sharma $S$, Parle $M$, Harna RK. 2011. Hypolipidemic and Weight Reducing Activity of the Ethanolic Extract of Tamarindus indica Fruit Pulp in Cafeteria Diet- and Sulpiride-induced Obese Rats. Journal of Pharmacology and Pharmacotherapeutics Vol 2 issue 2 pp 8084

11. Iftekhar ASMM, Rayhan I, Quadir MA, Akhteruzzaman S, Hasnat A. 2006. Effect Of Tamarindus indica Fruits On Blood Pressure And Lipid-Profile In Human Model: An In Vivo Approach. Pak. J. Pharm. Sci. Vol.19(2), 125-129 
ISSN 1978-2071 (Print); ISSN 2580-5967 (Online) Jurnal IImiah Kedokteran Wijaya Kusuma 6 (1) : 1-7

12. Currie E, Schulze A, Zechner R, Walther TC, Farese RV. 2103. Cellular Fatty Acid Metabolism and Cancer. Cell Metabolism 18:153-161

13. Liu H, Liu Y, Wu X and Zhang J. 2010. Biochemistry, Molecular Biology, and Pharmacology of Fatty Acid Synthase, an Emerging Therapeutic Target and Diagnosis/Prognosis Marker. Int J Biochem Mol Biol 1(1):69-89 
ISSN 1978-2071 (Print); ISSN 2580-5967 (Online) Jurnal IImiah Kedokteran Wijaya Kusuma 6 (1) : 1-7 